\title{
Author Correction: The role of the secretin/secretin receptor axis in inflammatory cholangiocyte communication via extracellular vesicles
}

\author{
Keisaku Sato ${ }^{1,2,3}$, Fanyin Meng ${ }^{1,2,3,4}$, Julie Venter ${ }^{1,2,3}$, Thao Giang ${ }^{1,2,3}$, Shannon Glaser ${ }^{1,2,3}$ \& \\ Gianfranco Alpini ${ }^{1,2,3}$
}

Correction to: Scientific Reports https://doi.org/10.1038/s41598-017-10694-3, published online 11 September 2017

This Article contains typographical errors in the Acknowledgements section.

“This work was supported by the Dr. Nicholas C. Hightower Centennial Chair of Gastroenterology from Baylor Scott \& White, a VA Research Career Scientist Award and a VA Merit award to Dr. Alpini (5I01BX000574), a VA Merit Award (5I01BX002192) to Dr. Glaser, a VA Merit Award (1I01BX001724) to Dr. Meng, and the NIH grants DK058411, DK076898, DK095291 and DK062975 to Drs. Alpini, Meng and Glaser."

should read:

"This work was supported by the Dr. Nicholas C. Hightower Centennial Chair of Gastroenterology from Baylor Scott \& White, a VA Research Career Scientist Award and a VA Merit award to Dr. Alpini (5I01BX000574), a VA Merit Award (5I01BX002192) to Dr. Glaser, a VA Merit Award (1I01BX001724) to Dr. Meng, and the NIH grants DK058411, DK076898, DK107310 and DK062975 to Drs. Alpini, Meng and Glaser."

(c) (i) Open Access This article is licensed under a Creative Commons Attribution 4.0 International License, which permits use, sharing, adaptation, distribution and reproduction in any medium or format, as long as you give appropriate credit to the original author(s) and the source, provide a link to the Creative Commons license, and indicate if changes were made. The images or other third party material in this article are included in the article's Creative Commons license, unless indicated otherwise in a credit line to the material. If material is not included in the article's Creative Commons license and your intended use is not permitted by statutory regulation or exceeds the permitted use, you will need to obtain permission directly from the copyright holder. To view a copy of this license, visit http://creativecommons.org/licenses/by/4.0/.

(C) The Author(s) 2018

\footnotetext{
${ }^{1}$ Research, Central Texas Veterans Health Care System, Temple, TX, 76504, USA. ${ }^{2}$ Department of Medicine, Texas A\&M College of Medicine, Temple, TX, 76504, USA. ${ }^{3}$ Baylor Scott \& White Digestive Disease Research Center, Baylor Scott \& White Healthcare, Temple, TX, 76504, USA. ${ }^{4}$ Academic Research Integration, Baylor Scott \& White Healthcare, Temple, TX, 76504, USA. Fanyin Meng, Shannon Glaser and Gianfranco Alpini jointly supervised this work. Correspondence and requests for materials should be addressed to F.M. (email: FMeng@medicine.tamhsc. edu) or S.G. (email: SGlaser@medicine.tamhsc.edu) or G.A. (email: GAlpini@medicine.tamhsc.edu)
} 